\title{
Subjective determinants of the development of foreign language teacher expertise ${ }^{1}$
}

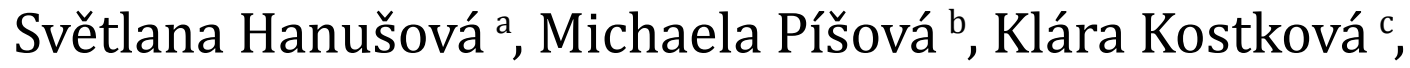 \\ Věra Janíková ${ }^{\mathrm{d}}$, Petr Najvar ${ }^{\mathrm{b}}$ \\ ${ }^{a}$ Masaryk University, Faculty of Education, Department of English Language and Literature \\ ${ }^{\mathrm{b}}$ Masaryk University, Faculty of Education, Institute for Research in School Education \\ ${ }^{\mathrm{c}}$ Charles University, Faculty of Education, Department of English Language and Literature \\ ${ }^{\mathrm{d}}$ Masaryk University, Faculty of Education, Department of German Language and Literature
}

Received 13 July 2014; final version received 23 November 2014; accepted 24 November 2014

Abstract: The paper presents partial results of a research project dealing with the nature of expertise of foreign language teachers. Whereas the first two phases of the project focused on expert teacher's performance, knowledge base and insight from a synchronous perspective, the third phase of the research was diachronically oriented and was aimed at identifying both subjective and objective determinants of the development of teacher expertise. In the current paper we present the results concerning subjective determinants of their professional development. The data were collected in narrative interviews with 8 teachers of English or German at Czech lower secondary schools. The following categories were induced through open coding of verbal protocols: the teacher's self-knowledge, their intrinsic motivation, value system, job satisfaction, openness to change and coping with the demands of the profession. The results contribute to understanding of the processes of developing and maintaining expertise and to understanding of the needs of teachers and the development of the supporting processes of their professional development.

Keywords: professional development, foreign language teacher, narrative interview, teacher expertise, subjective determinants

The tradition of exploring outstanding performance in various domains of human activities is reasonably long and it can be stated that in recent decades it has gone through a dynamic development. Research into expertise is now being conducted in teaching, both at the general level and in the context of individual subcultures of the teaching profession. It is based on research

\footnotetext{
1 The research was supported by the grant P407/11/0234 Expert Teacher: the nature of expertise and determinants of professional development (in foreign language teaching perspective) provided by the Czech Science Foundation.
} 
into expertise in other domains, on the theory of expertise as a phenomenon exlusively linked to professions (Bromme \& Tillema, 1995, p. 264), and also on theory and research on teachers and teaching.

The current trends in teacher research and theory include (1) the conception of teaching as reflective practice, (2) the conception of evidence-based teaching and (3) the conception of knowledge-based teaching (for more information see Píšová et al., 2011, p. 43).

In parallel with the above approaches in teacher research, in which expertise is understood rather as a state, in the last few decades research focusing on the development process of expertise in teachers and the factors that influence this process has been carried out. In the area of teacher professional development it is possible to trace two different methodological approaches which Chi (2006, pp. 21-23) refers to as the absolute and the relative approaches, namely: (1) research which depicts individually selected aspects or rather phases of teacher professional development (e.g. Tsui, 2003) and (2) comparative studies deploying a relative approach, i.e. studies aimed at comparing teachers at different stages in their developmental trajectories, mostly novices and expert teachers (e.g. Joyce \& Showers, 2002; Kyriakides, Creemers, \& Antoniou, 2009), but also (narrative) biographical studies of one's own professional development (e.g. Bullough, 2008). The research presented in this paper was conceived in the spirit of an absolute approach, focusing on the expert stage of the professional development of teachers only.

In the last stage of our long-term research project aimed at the nature of foreign language teacher expertise, we analyzed the determinants of the processes of expertise development and maintenance in teachers of English and German as foreign languages at Czech lower secondary schools. We focused on variables that do not concern only the personality and individual characteristics of teachers, but also on selected variables related to the institutional and socio-cultural context of their work. In this sense, we followed on the study carried out by Fessler and Christensen (1992), Huberman (1993), Kelchtermans and Vandernberghe (1993), and Day et al. (2007). For the purpose of analysis of the determinants of professional development of foreign language teachers and their journeys to reaching and maintaining expertise, we used Pařízek's conceptualization and terminology (1994,pp.61-67), i.e. the division of the subjective and objective determinants of career development. Whereas objective determinants are external factors which directly influence the teacher, their performance, attitudes to the 
profession and their professional career (such as the economic, political and cultural environment, including the broader social community in which the teacher operates, pre-service and continuing teacher education, family/ personal life conditions, or school as an institution), subjective determinants are internal factors directly related the the individuality of the teacher. Although our research dealt with both types of determinants, in this study we will present only the results relating to the subjective ones.

\section{Subjective determinants of professional development}

The subjective determinants of the development of expertise are considered to be a complex dynamic set of interacting factors that are directly related to a teacher, evolving over time and highly relevant to the professional development of teachers. The importance of these determinants is underlined by the fact that the professional development of teachers cannot be separated from their personal growth. Personal and professional development should be understood as one process that takes place in the continuity of the life of a teacher (Goodwin, 2005, p. 231). The theme of subjective determinants is studied more closely in Píšová et al. (2011).

Currently, complex models of personality, such as the so-called Big Five (emotional stability, extraversion, agreeableness, conscientiousness, openness to experience), are typically employed to analyze subjective determinants of teacher professional development (Barrick \& Mount, 1991; similarly, current studies such as Jacob et al., 2009, etc.). A number of empirical studies deal with different aspects of teacher cognition (e.g. cognitive styles, Skehan, 2000; Sadler-Smith et al., 2000, etc.).

Attention is paid to the character and moral qualities of teachers (Sockett, 1993), however, the areas of the emotional, volitional, attitudinal and ethical aspects of the development of expertise have been explored to a lesser extent.

Emotions are closely linked with self-system, with the professional "self" of a teacher, which is currently perceived as multifaceted, i.e. as a hierarchical structure of the dynamics of the functioning and the procedural and structural interconnection of "self". Studies in teachers and teaching agree that teachers interpret and construct their experience and conception of the profession based on their knowledge of "self" (Kelchtermans, 1993), and that the way in which they perform their professional activities is closely tied to the events and experiences of their personal lives (Ball \& Goodson, 1985). 
The components of teacher professional "self", to which great attention is currently paid, include self-efficacy. Bandura (1997) defined self-efficacy as beliefs about one's own ability to perform in specific situations. There are a number of instruments for measuring self-efficacy in teachers. One of the most widely used is the Teacher Efficacy Scale (Gibson \& Dembo, 1984) that includes two dimensions: personal teaching efficacy (a teacher's expectation that they will be able to facilitate students' learning) and general teaching efficacy (the belief that external factors, especially the current institutional form of education, can positively influence students' learning).

Ross (1994, p. 382) claims that teacher efficacy is a key variable predicting teacher practice and student outcomes. He found out that the inexperienced teachers display a low level of personal self-efficacy and trust the educational system more than themselves. The experienced teachers showed a higher level of personal efficacy but less trust in the educational system. They believed that the success of the educational process is influenced by factors beyond school control.

In teacher research and theory the concept of professional identity is frequently brought up in relation to self-system (Day, 2004, p. 53). This is also examined in the context of professional development towards expertise: see Beijaard et al. (2000), who examined the development of the conception of identity amongst experienced secondary school teachers. They assumed that the teacher's perception of their identity has a significant impact on their self-efficacy and ability to cope with the demands of the profession and implement innovations in their practice. They identified differences between the perception of identity amongst teachers at the beginning of their career and after gaining some experience. Early in their careers, the identity of a large number of teachers was bound to their subject matter, while later most teachers viewed their identity as balanced in all three dimensions, namely in the subject matter expertise, in the didactical dimension (e.g. planning, realization and evaluation of the teaching process) and in pedagogical expertise (e.g. support of students' social, emotional and moral development). Only a minority perceived dominance in the didactical dimension. Identity anchored in expert mastery of their subject and of didactics occurred significantly more frequently than identity rooted in pedagogical expertise (Beijaard et al., 2000, pp. 756-758). 
The process of teacher professional development and the shaping of their career paths are influenced by a number of other subjective factors. These include coping strategies (e.g. Sikes et al., 1985; Pollard, 1982; Woods, 1981), reflective potential of individuals (King \& Kitchener, 1994), attribution, extent of professional autonomy, and others. Clement and Vandenberghe (2000, p. 87) also considered job satisfaction to be an important factor. $A$ sense of commitment and dedication to the profession are generally considered to be the crucial core factors (Day, 2004).

\section{Research: subjective determinants of the development of expertise among foreign language teachers}

\subsection{Research context}

The presented study was part of a long-term research project Expert Teacher: the nature of expertise and determinants of professional development (in foreign language teaching perspective) focused on foreign language teachers' expertise as the highest measure of quality of their teaching performance. The research was designed as a multiple case study.

In the period from 2011 to 2013 we worked with 30 outstanding teachers of English and German, who taught at lower-secondary schools in the Czech Republic and who were initially recruited on the basis of social nominations, length of experience and professional qualifications. In the first and second stages of the research we looked at the expertise of teachers from a synchronous perspective: we focused first on directly observable features of expertise and later also on features unavailable to direct observation. Furthermore, we also used the method of stimulated recall to capture the teachers' thinking while teaching and about teaching. In the third and final stage the expertise of foreign language teachers was viewed diachronically, i.e. in terms of the development of a particular teacher.

The article presents partial results of the analysis of the data from this last stage, in which the aim was to analyze the factors that determined the processes of expertise development and maintenance.

The main research question for the third phase of our research into foreign language teacher expertise was: What are the determinants for achieving and maintaining expertise among teachers of a foreign language? 
The search for answers to this research question included an analysis of the subjective and objective variables which affected the professional development of teachers and the achievement and maintenance of expertise. As mentioned above, only the findings related to subjective determinants are presented here.

\subsection{Research methods and sample}

The research sample consisted of 8 expert teachers of English $(n=6)$ and German $(n=2)$ at lower secondary schools in the Czech Republic $\left(n_{f}=6\right.$, $n_{m}=2$ ), who were identified on the basis of the results of previous phases of this multiple case study. A choice was made from the initial sample $(n=30)$ of teachers who in earlier phases of the research project had shown most features of expert performance and thinking. To mark the teachers we used codes beginning with the letter $\mathrm{T}$ (= teacher). The numbers in the codes are in the range of 1 to 30 , which corresponds to the code established in the first phase of the research even though only eight teachers were interviewed in the third phase (T6, T8, T11, T14, T21, T22, T27, T30).

The research phase was designed as qualitative. The instrument for data collection was in-depth interviews with narrative elements (the length of the interview was 30-45 min), followed by a phase of communicative validation and deepening insight into the life stories of the respondents through dialogic written form (e-mail communication with respondents). The process of data collection was based on the principles of biographical research (Marotzki, 2004; Roberts, 2002); within the analysis of the data a realist approach to biography was applied (Miller, 2000, pp. 96-98). The realist approach stems from grounded theory and involves the discovery and construction of concepts directly from the data. The view of the respondent per se is accepted, that is the assumption that the reality can be recognised through the account of the participant.

Mutual trust between the researcher and the respondent, which had been established during the meetings in the previous phases of the research, served as an advantage as it is one of the conditions necessary for the successful realization of biographical research. Before starting the interview, respondents were asked to think about so-called "chapters of the book of their professional life": 
Please begin by thinking about your life as if it were a book or a novel. Imagine that the book has a table of contents containing the titles of the main chapters in the story. To begin here, please describe very briefly what the main chapters in the book might be. Please, give each chapter a title, tell me just a little bit about what each chapter is about, and say a word or two about how we get from one chapter to the next. As a storyteller here, what you want to do is to give me an overall plot summary of your story, going chapter by chapter. You may have as many chapters as you want, but I would suggest having between about two and seven of them. (McAdams, 2007, unpaged)

The researchers did not intervene in the narration, they simply encouraged the respondent with standard probes if necessary.

With the consent of the respondents, the interviews were audio recorded, transcribed and then subjected to content analysis. An idea unit represented the unit of analysis for coding.

Regarding subjective determinants of achieving and maintaining expertise, during the pilot phase of the analysis we attempted to analyse against a roughly-grained system of categories derived from theory, however, it proved to be impossible to capture the complex set of interacting subjective determinants in this way. Therefore the idea units related to the subjective determinants of teacher professional development were firstly collected under the "assembly code" (SD) and then analyzed inductively. As regards data processing, after this initial marking and cutting of text all the identified quotes were sorted. As the aim of the analysis was to uncover all the factors that the teachers brought up in relation to their professional trajectories, all the identified idea units were included into the sorting, which then involved arranging the quotes into piles of things that go together. There are many variations on this technique. Lincoln and Guba (1985, pp. 347-351) offered a detailed description of the cutting and sorting technique with the method of constant comparison which is much like the pile-sorting task used extensively in cognitive research. Ryan and Bernard (2003, pp. 95-97) present further variations which mostly aim at increasing the trustworthiness of the results, for example sorting the piles by two independent researchers or by larger teams deploying more sophisticated analytical procedures such as a twophase coding process (e.g. Barkin, Ryan, \& Gelberg, 1999; Jehn \& Doucet, 1996). In our case the data processing was carried out in the following steps: (1) cutting and sorting by one researcher; and (2) dialogical validation by two more members of the research team. The resulting subcategories and their grouping into major categories are presented further in this paper. 


\subsection{Research results}

A set of categories and concepts summarized in Table 1 emerged as the result of the content analysis of verbal protocols of narrative interviews. In the subsequent discussion the particular determinants and subcategories are interpreted in detail and illustrated by authentic statements.

Table 1

Subjective determinants of the professional development of an expert teacher

\begin{tabular}{|c|c|}
\hline Determinant & Subcategory \\
\hline $\begin{array}{l}\text { self-knowledge - (perceived) } \\
\text { prerequisites for the profession }\end{array}$ & $\begin{array}{l}\text { (a) giftedness for teaching } \\
\text { (b) relationship to children, or interest in people } \\
\text { in general } \\
\text { (c) relationship to the subject matter, enthusiasm } \\
\text { for / interest in foreign languages and culture } \\
\text { (d) consistency, perseverance } \\
\text { (e) self-evaluation, self-reflection }\end{array}$ \\
\hline intrinsic motivation & $\begin{array}{l}\text { (a) long-term interest in the profession } \\
\text { (b) sense of belonging to the profession }\end{array}$ \\
\hline value system & teaching as a vocation \\
\hline job satisfaction & $\begin{array}{l}\text { (a) self-efficacy: feeling of contentment from / } \\
\text { awareness of good work, self-fulfilment } \\
\text { (b) awareness / appreciation of autonomy } \\
\text { (c) job satisfaction }\end{array}$ \\
\hline $\begin{array}{l}\text { openness to change, active search } \\
\text { for ways leading to professional } \\
\text { development/improvement of one's own } \\
\text { practice }\end{array}$ & $\begin{array}{l}\text { (a) the need for improvement and an active } \\
\text { search for ways leading to professional } \\
\text { development / to improving one's own } \\
\text { practice } \\
\text { (b) accepting changes as new challenges and a } \\
\text { professional change as a positive step in one's } \\
\text { career path }\end{array}$ \\
\hline $\begin{array}{l}\text { perceived demands of the teaching } \\
\text { profession and coping with stress }\end{array}$ & $\begin{array}{l}\text { (a) demands of the teaching profession } \\
\text { (especially entry into the profession) } \\
\text { (b) coping strategies and mental health }\end{array}$ \\
\hline
\end{tabular}

In the field of subjective determinants 107 idea units were identified through the open coding and the statements came from all 8 of the expert teachers involved in the research. The number of codes for each teacher was relatively comparable but the distribution of categories was uneven, which suggests that teachers emphasise different issues and have different needs on their path to expertise. This finding is consistent with the results of other studies for example Day and Gu (2010, pp. 51-52) who stated that the significance 
of the influence of subjective determinants in shaping the professional lives of teachers varies in individuals. Furthermore, we are aware that with subjective determinants the intimate character of the data may play a role.

\section{Category 1: Self-knowledge and perceived prerequisites for the profession}

In the first category, five sub-categories are included, namely (a) giftedness for teaching; (b) relationship to children or interest in people in general; (c) relationship to the subject matter, enthusiasm for / interest in foreign languages and culture; (d) consistency, perseverance, and (e) self-evaluation, self-reflection.

(a) Some teachers relate the quality of their performance in their profession, especially at an early stage of their professional life, to an unspecified "gift" for teaching, an innate endowment / prerequisite for being able to teach. Awareness of "giftedness" is an indicator of the strength of their inner conviction about appropriatness of their choice of profession, which contributes to the strengthening of expert teachers' professional confidence.

I think I must have had some kind of innate ability because right from the start I didn't really have any problems with it, it went quite well. (T27)

(b) The perceived prerequisites for the teaching performance relate mainly to a love for children and a strong positive relationship to them (sometimes in the form of a more general interest in people). Based on the results of previous research phases in this multiple case study and on other research and theoretical studies (Helus, 2009), it can be deduced that the condition for such relationship is a deep insight into the personality of the child. A strongly articulated awareness of one's own communication skills is essential not only for the relationship between teacher and pupil, but also for the mutual relationships between the various agents in the educational process (colleagues, superiors, parents and possibly institutions).

(c) Based on the relatively high frequency of statements in which teachers expressed their deep relationship to the subject matter they teach and their enthusiasm, in our case a deep interest in foreign languages, which they perceived primarily as a means to explore the world, other cultures and as a key that opens the gate of mutual understanding, 
this frequently represented subjective determinant can be identified as a key to professional development. The question is whether this is a domain-specific subcategory or whether having a relationship to one's field is a domain-general phenomenon (cf. Borg, 2006 for teachers of foreign languages).

And when I started doing a retraining course, I was in my element. I was finally studying something that I had always wanted to study, I was working with children just as I had always wanted to do and I was teaching German, which I love. So the dream I'd had when I was about 15 had come true - that I would teach children and work with foreign languages. (T8)

(d) Consistency, or perseverance, which proved to be one of the key prerequisites for achieving good results, is a typical characteristic of an expert teacher (cf. similar results from research in the USA, Ripley, 2010). Here it appears to be associated with target orientation (i.e. the ability to set specific goals and conditions necessary for attaining these goals, as well as the ability to consciously and persistently strive to a chieve them in the long run). Perseverance and consistency can be seen as a willingness to work together, to develop, it can be viewed as a "tool" - a strategy, as a characteristic necessary for overcoming barriers to achieving the goals they have set. Expert teachers perceive goals not only as a conscious direction for their activity, but also in terms of a model to work towards (ideals or vivid mental images of something subjectively perceived positively - for example a model of the "ideal teacher"), i.e. a commitment to quality ("to do it well").

[At] university I had to look after myself and pay my own way, so it was my own kind of private project which I wanted to finish, I had to prove something to myself and it was something that I really, that I saw as really important to do. Something I would be successful in. And unlike a lot of my classmates, I always knew that I wanted to teach. I didn't know who or what, but I knew that during my life I would teach. (T6)

(e) Statements of a reflective and self-reflective nature appeared very often (cf. study by Dirks \& Hansmann, 1999), and in the interviews most of them are "deeper-level" self-reflections reaching at the level of metacognition, and of realistic professional self-evaluation including implications for deciding the course of their professional trajectory (cf. Schön, 1983; Eraut, 1994; Tsui, 2005). It is quite clear that self-reflection is built on 
balance, a positive self-image and a well-defined professional identity. The statements show that expert teachers perceive, describe and assess their thinking, emotions, attitudes and behaviour, and try to discover the causes of their actions, to infer the consequences and explore new avenues, set goals, and are able to use self-reflective techniques.

Well, then one more stage happened, when I just... I just don't have anywhere to go any more, I've hit the limit of where I can get in my field. First, my intellect doesn't allow me to go any further, and my age no longer allows me to progress and I am at this school in a position that is quite a lot of work, so I feel like I am stuck in a rut at the level of where I am, and I try to give back a lot. (T27)

\section{Category 2: Intrinsic motivation}

The category contains two sub-categories: (a) long-term interest in the profession and (b) the sense of belonging to the profession. In this category there were fewer results in terms of both the number of statements and the total number of respondents.

a) Amongst expert teachers the above conditions for the teaching profession, especially giftedness, and also some personal characteristics (persistence, consistency) in conjunction with internal motivation took on the specific form of long-term interest in entering the profession, from the games the respondents used to play as children through to leadership roles in different social groups including in their school classes, to their actual entry into the profession. From a psychological point of view the respondents' expressed interest in the profession corresponds to people's internal driving force to pursue certain activities. Internal motivation belongs to fundamental and very important parts of the personality structure and is closely associated with the need for self-realization - in our case in the teaching profession. Intrinsic motivation is an essential component of commitment (cf. Guskey, 2002, p. 382). The source of motivation can also be an ideal (see above), with which expert teachers identify.

(b) For the expert teachers sense of belonging to the profession seems to be characteristic, even in the period when external/social reasons may not have allowed them to finish their studies at the usual time (after graduation from secondary school) or when in the course of their professional lives they left the profession temporarily. At the risk of sounding somewhat grandiose it may be stated that the teaching 
profession becomes a way of life more than simply a professional role. This interpretation is fully consistent with the core structure of teacher professionalism which Korthagen and Vasalos (2005, p. 53) referred to as mission. They understand its reflection as the process of "becoming aware of the meaning of our own existence in the world, and the role we see for ourselves in relation to our fellow man" (cf. also Day, 2004, etc.):

[on temporary change of employment] I didn't feel I wanted to stay there. I always had the feeling that I would go back to school. I did not know exactly when, I didn't plan that, but I knew that I didn't want to leave permanently. I never thought that. (T11)

\section{Category 3: Value system}

In the theory of the teaching profession and according to the results of empirical research the value system is usually considered to be one of the most important issues in teaching. Expert teachers perceive teaching as a mission, paying particular attention to the ethical aspects of the profession. They are in this sense the real representatives of moral professionalism (Sockett, 1993, p. 18), satisfying the requirement of "being professional" and "acting professionally", i.e. not only being first-quality teachers, but also working on the basis of an internal ethical code of the profession (McDonnell \& Pascal, 1988, p. 5). It is the moral and ethical mission of teaching which is a source of self-affirmation for them, making their own investment into professional development meaningful. The category of expert teachers' value system was not further structured in their statements.

Reflection on the internal ethical code of the profession shows that expert teachers have an individual professionally oriented value system that is important to them and also motivates them to do activities which they consider valuable within their "teaching mission".

A lot of people started to turn to jobs, which were easier or brought in more money or something, but when I thought about it, I realized that they just do not give you the satisfaction of someone needing you. And they really need me at the school. (T27)

\section{Category 4: Job satisfaction}

Within the category three sub-categories were observed, namely: (a) self-efficacy: feeling of contentment from/ awareness of good work, self-fulfillment; (b) awareness / appreciation of autonomy; (c) job satisfaction. 
(a) Expert teachers are aware of their good work and their statements show a high level of self-efficacy. This is associated with high rates of job satisfaction given by a sense of fulfilment, self-realization - of something that has meaning for themselves as well as for others and for society. Selfrealization is closely related to self-knowledge, with awareness of one's own individuality, but also the ability to make decisions (see autonomy below).

I am quite proud of the system [of teaching languages] which we have here. We have done a lot of work on it. It's like my baby - I look after it and I feel great about the fact that when I leave here in 20 years' time I will be able to take something with me, something I was able to influence, that I influenced it in the positive sense of the word. (T27)

(b) While carrying out their profession, teachers are usually in the classroom with the students by themselves behind closed doors. This aspect of a teacher's work is often experienced in terms of isolation (sometimes even painful) or lack of support (Lortie, 1975, p. 133; Huberman, 1993, p. 31; Píšová, 1999, pp. 40-42) but expert teachers actually appreciate this fact and perceive themselves as having a high degree of autonomy and freedom to make professional decisions and to take part in them.

[...] at the end of that year, I realised [...] that I didn't want to escape [...] I realised that teaching gives you quite a lot of possibilities because when you close the classroom door, you can do whatever you feel is appropriate, in the way that you think is right. (T27)

(c) Teachers sometimes only express job satisfaction emotionally without mentioning any specific sources or aspects of the profession itself.

I really enjoy it. If I didn't enjoy it, and I often say that to the pupils, if I didn't enjoy it, you wouldn't see me here tomorrow. Of course there are moments when, I don't want to exaggerate too much, when I'd like to give it all up and go and do something more useful. But I still really enjoy it. (T14)

In some cases, expert teachers link the feeling of job satisfaction to a specific context, especially to a school which they perceive as different in some way, or they may be emotionally bound to it because they attended it as pupils themselves. They report an intense sense of belonging, of "safety", which they subjectively perceive very strongly. This intense feeling of being a recognized/ accepted member of the community reinforces self-confidence, self-esteem 
and a sense of shared benefit. This sub-category is very closely linked to the objective determinants of career development (see also Píšová et al., 2011, chapters 2 and 4 ).

Category 5: Openness to change, active search for ways leading to professional development / to improving one's own practice

The category appeared in the analysis as relatively "strong" especially with regard to the number of statements referring to it. The individual subcategories induced included: (a) the need for improvement and an active search for ways to improve and (b) accepting changes as new challenges and a professional change as a positive step in one's career path. Openness to change may be associated with the high degree of reflectivity of expert teachers (see the category of self-knowledge above).

(a) The view of expertise as a dynamic concept (Bereiter \& Scardamalia, 1993) is echoed in the high frequency of statements which thematise the active search for ways to improve, innovations (competent teacher as a "multiplier of innovations" - Gruber \& Leutner, 2003) leading to professional development, fear of stagnation and the need for continuous improvement and the willingness of expert teachers to invest in activities that promise to support their professional development.

(b) The attitude of teachers towards educational change is currently a burning issue in teacher theory and research. Educational change as a de facto permanently present aspect of teachers' lives (Hargreaves, 1998) is not only accepted by expert teachers, but its manifestations are perceived as new challenges, and changes are seen as positive steps in their careers. This fact is also related to consistency and perseverance as well as to intrinsic motivation. Expert teachers' positive perception of the need for change greatly outweighs the often negative perception of change on the part of colleagues, parents and society.

I really didn't want to do it [to be deputy head and teach English] because I was very happy teaching small children. But then I realized that it might actually be quite nice to try something else. Anyway, I agreed to do it [...] when I look back, even at home, when we talk about it, I always say that it was a wonderfully positive and amazingly good step. (T11) 
Category 6: Perceived demands of the teaching profession and coping with stress

The last category identified is divided thematically into two sub-categories: (a) demands of the teaching profession (especially entry into the profession) and (b) coping strategies and mental health.

(a) The demands of the teaching profession are often mentioned by respondents in connection with entry to the profession. This finding is consistent with the results of a number of empirical studies which clearly indicate professional initiation as the critical period in which the professional identity of teachers is shaped (Cherubini, 2009). The difficulty is confirmed by the high percentage of young/novice teachers who leave the profession; some of the commonly reported causes are also thematised by respondents in this research (Píšová, 2013). Expert teachers reflect sensitively on their entry into the profession which they often describe as the most demanding phase of their professional lives, but they also understand it as a natural stage as evidenced by the abovementioned determinants (perseverance, relationship to the profession, demands they placed on themselves, etc.).

It was quite a sink or swim start and unfortunately I feel I didn't manage it that well, there was so much to do but I really enjoyed it, and to be honest I liked being at that school. So I stayed there and I'm happy. (T14)

(b) It is generally recognized that teaching, as a helping profession, is an occupation with a heavy burden of stress (Hennig \& Keller, 1996 etc.). For expert teachers their commitment to the profession and heavy workload are so time-consuming that as a result there is often a clash with personal/family life and its demands (Rothland, 2013). A number of the statements refer to finding a balance between professional and personal life. Expert teachers are able in retrospect to identify particular "breaking points" or "critical events" that caused them to change and to actively seek ways of coping with being stressed and overloaded (cf. Švaříček \& Šed'ová et al., 2007, pp. 335-352):

Actually, because I spent an awful lot of time on my work, I didn't give my family my full attention, I gave it to my work and so a lot of things just passed me by and I had to make up for it later. At some time, it was, I think, in about 2006, I suddenly realized that I had too much work. Really too much, and I began to look for a way to organize it, to manage everything. (T14) 
Stress management strategies are an important theme in the teaching profession. Expert teachers are aware of the threat of burnout syndrome, at certain stages of their professional life some of them were directly at risk of experiencing it themselves. However, the statements suggest that these teachers are able to implement stress prevention strategies, are able to identify the danger signs and in the case of increased workload they can activate their self-defence mechanisms and actively search for the optimal solution to the situation. These skills affect the quality of their performance positively, increase their satisfaction and strengthen their teacher identity (Alsup, 2005; Zembylas, 2003).

\section{Conclusion}

During the investigation focused on the development and maintenance of expertise in foreign language teachers we were able to identify subjective determinants of the process through inductive analysis of narrative interviews.

The view of subjective determinants as a complex and dynamic set of interconnected factors with a direct effect on the individual teacher proved to be well-applicable. The breakdown of these determinants into the six categories at which we arrived can thus serve mainly for the purpose of analysis and description of the determinants although in reality these cannot be separated. Within the set of subjective determinants the teacher's selfawareness, their grounding in self-reflection, their ability to express their conviction about their own aptitude for the profession, their interest in working with children and their interest in the subject matter, and at the same time their consistency and perseverance in achieving the objectives they have set, play an important role. Expert teachers also showed intrinsic motivation, which manifests itself through passion for the profession.

Ethical values play a significant role in the teaching profession and expert teachers intentionally aim towards the materialisation and implementation of them; they are distinctly perceived as part of the mission of a teacher. The job satisfaction of expert teachers draws primarily on their self-efficacy, but also stems from their positive feelings towards the nature of their work as well as from their satisfaction with specific institutions and a sense of belonging to them. Expert teachers are also characterized by their openness to change and their constant desire to perfect their own performance and 
to search for new approaches. Regarding the undisputed demands of the profession, teachers certainly perceive them but are nonetheless able to find effective coping strategies.

We believe that these results are useful for both understanding the processes of developing and maintaining expertise and for understanding the needs of teachers and the development of the supporting processes of their professional development in general. We are aware of the limitations of the methodology and the scope, such as the limited generalizability of the research results and the character of realist biography which looks at reality solely through the participants. The approach to data analysis also presents certain limits. These are mainly related to the aims of the research and possible limitations of the data obtained, which due to their nature could be specified later as is normal in biographical research. We consider this an important impetus for further research in the domain of professional development for teachers on their journey to expertise.

\section{Acknowledgements}

The authors thank Ailsa Randall, M.A., for translating the paper from Czech to English.

\section{References}

Alsup, J. (2005). Teacher identity discourses: Negotiating personal and professional spaces. New York: Routledge.

Ball, S. J., \& Goodson, I. F. (1985). Understanding teachers: Concepts and contexts. In S. J. Ball \& I. F. Goodson (Eds.), Teachers' lives and careers (pp. 1-26). London: The Falmer Press.

Bandura, A. (1997). Self-efficacy. The exercise of control. New York: W. H. Freeman and Comp.

Barkin, S., Ryan, G., \& Gelberg. L. (1999). What pediatricians can do to further youth violence primary prevention: A qualitative study. Injury Prevention, 5(1), 53-58.

Barrick, M. R., \& Mount, M. K. (1991). The big five personality dimensions and job performance: A meta-analysis. Personnel Psychology, 44(1), 1-26.

Beijaard, D., Verloop, N., \& Vermunt, J., D. (2000). Teachers' perceptions of professional identity: An exploratory study from a personal knowledge perspective. Teaching and Teacher Education, 16(7), 749-764.

Bereiter, C., \& Scardamalia, M. (1993). Surpassing ourselves: An inquiry into the nature and implications of expertise. Chicago: OpenCor.

Borg, S. (2006). The distinctive characteristics of foreign language teachers. Language Teaching Research, 10(1), 3-31.

Bromme, R., \& Tillema, H. (1995). Fusing experience and theory: The structure of professional knowledge. Learning and Instruction, 5(4), 261-269. 
Bullough, R. V. (2008). The writing of teachers' lives - Where personal troubles and social issues meet. Teacher Education Quarterly, 35(4), 7-26.

Cherubini, L. (2009). Reconciling the tensions of new teachers' socialisation into school culture: A review of the research. Issues in Educational Research, 19(2), 83-99.

Chi, M. T. H. (2006). Two Approaches to the study of experts' characteristics. In K. A. Ericsson, N. Charness, P. J. Feltovich, \& R. R. Hoffman (Eds.), The Cambridge handbook of expertise and expert performance (pp. 21-30). New York: CUP.

Clement, M., \& Vandenberghe, R. (2000). Teachers' professional development: A solitary or collegial (ad)venture? Teaching and Teacher Education, 16(1), 81-101.

Day, Ch. (2004). A passion for teaching. London: Routledge Falmer.

Day, Ch., \& Gu, Q. (2010). The new lives of teachers. London: Routledge.

Day, C., Sammons, P. Stobart, G., Kington, A., \& Quing, G. (2007). Teachers matter: Connecting work, lives and effectiveness. Oxford: McGraw Hill.

Dirks, U., \& Hansmann, W. (Eds.). (1999). Reflexive Lehrerbildung: Fallstudien und Konzepte im Kontext berufsspezifischer Kernprobleme. Weinheim: Deutscher Studien Verlag.

Eraut, M. (1994). Developing professional knowledge and competence. London: The Falmer Press.

Fesler, R., \& Christensen, J. (1992). The teacher career cycle: Understanding and guiding the professional development of teachers. Boston: Allyn \& Bacon.

Gibson, S., \& Dembo, M. (1984). Teacher efficacy: A construct validation. Journal of Educational Psychology, 76(4), 569-582.

Goodwin, D. R. (2005). Comprehensive development of teachers based on in-depth portraits of teacher growth. In D. Beijaard et al. (Eds.), Teacher professional development in changing conditions (pp. 231-243). Berlin: Springer.

Gruber, H., \& Leutner, D. (2003). Die kompetente Lehrperson als Multiplikator von Innovation. In R. Tippelt \& I. Gogolin (Eds.), Innovation durch Bildung. Beiträge zum 18. Kongress der Deutschen Gesellschaft für Erziehungswissenschaft (pp. 263-274). Opladen: Leske + Budrich.

Guskey, T. R. (2002). Professional development and teacher change. Teachers and Teaching: Theory and Practice, 8(3/4), 381-391.

Hargreaves, A. (1998). The emotions of teaching and educational change. In A. Hargreaves, A. Lieberman, M. Fullan, \& D. Hopkins (Eds.), International handbook of educational change (pp. 558-575). Dordrecht: Kluwer.

Helus, Z. (2009). Dítě v osobnostním pojetí. Praha: Portál.

Hennig, C., \& Keller, G. (1996). Antistresový program pro učitele. Praha: Portál.

Huberman, M. (1993). The lives of teachers. London: Cassell.

Jacob, B. A., Kane, T. J., Rockoff, J. E., \& Staiger, D. O. (2009). Can you recognize an effective teacher when you recruit one? CLOSUP Working Paper Series Number 11. Retrieved from http:// www.gse.harvard.edu/cepr-resources/files/news-events/ncte-recognize-effectiveteacher--jacob-kane-rockoff.pdf

Jehn, K. A., \& Doucet, L. (1996). Developing categories from interview data: Text analysis and multidimensional scaling. Part 1. Cultural Anthropology Methods Journal, 8(2), 15-16.

Joyce, B., \& Showers, B. (2002). Student achievement through staff development (3rd ed.). New York: Longman.

Kelchtermans, G. (1993). Teachers and their career story: A biographical perspective on professional development. In C. Day, J. Calderhead, \& P. Denicolo (Eds.), Research on teacher thinking: Understanding professional development (pp. 198-220). London: Falmer Press. 
Kelchtermans, G., \& Vandenberghe, R. (1993). A teacher is a teacher is a teacher is a... Teachers' professional development from a biographical perspective. Paper presented at the annual meeting of the American Educational Research Association, Atlanta, 1993. Retrieved from http://www.eric.ed.gov/

King, P. M., \& Kitchener, K, S. (1994). Developing reflective judgment: Understanding and promoting intellectual growth and critical thinking in adolescents and adults. San Francisco: Jossey-Bass Publishers.

Korthagen, F. A. J., \& Vasalos, A. (2005). Levels in reflection: Core reflection as a means to enhance professional growth. Teachers and Teaching: Theory and Practice, 11(1), 47-71.

Kyriakides, L., Creemers, B. P. M., \& Antoniou, P. (2009). Teacher behaviour and student outcomes: Suggestions for research on teacher training and professional development. Teaching and Teacher Education, 25(1), 12-23.

Lincoln, Y. S. \& Guba, E. G. (1985). Naturalistic inquiry. Beverly Hills: Sage.

Lortie, D. (1975). Schoolteacher: A sociological study. Chicago: University of Chicago Press.

Marotzki, W. (2004). Qualitative biographical research. In U. Flick, E. von Kardoff, \& I. Steinke, A companion to qualitative research (pp. 101-107). London: Sage.

McAdams, D. P. (2007). The life story interview. Retrieved from http://www.sesp.northwestern. edu/docs/LifeStoryInterview.pdf

McDonnell, L., \& Pascal, A. (1988). Teacher unions and educational reform. Santa Monica: Center for Policy Research in Education.

Miller, R. L. (2000) Researching life stories and family histories. Introducing qualitative methods. London: Sage.

Pařízek, V. (1994). Obecná pedagogika. Praha: Univerzita Karlova.

Píšová, M. (1999). Novice teacher. Sci. Pap. Series C, Supplement 1. Pardubice: University of Pardubice.

Píšová, M., Najvar, P., Janík, T., Hanušová, S., Kostková, K., Janíková, V., Tůma, F., \& Zerzová, J. (2011). Teorie a výzkum expertnosti v učitelské profesi. Brno: Masarykova univerzita.

Píšová, M. (2013). Teacher professional socialisation: Objective determinants. Orbis Scholae, $7(2), 67-80$.

Pollard, A. (1982). A model of classroom coping strategies. British Journal of Sociology of Education, 3(1), 19-37.

Ripley, A. (2010). What makes a great teacher? The Atlantic Magazine, January 1, 2010. Retrieved from http://www.theatlantic.com/magazine/archive/2010/01/what-makes-a-great-teacher/307841/3/

Roberts, B. (2002). Biographical research. Buckingham: Open University Press.

Ross, J. A. (1994). The impact of an in-service to promote cooperative learning on the stability of teacher efficacy. Teaching and Teacher Education, 10(4), 381-394.

Rothland, M. (2013). Belastung und Beanspruchung im Lehrerberuf: Modelle, Befunde, Interventionen. Münster: Springer.

Ryan, G. W., \& Bernard, H. R. (2003). Techniques to identify themes. Field Methods, 15(1), 85-109.

Sadler-Smith, E., Allinson, C. W., \& Hayes, J. (2000). Cognitive style and learning preferences: Some implications for CPD. Management Learning, 31(2), 239-256.

Schön, D. A. (1983). The reflective practitioner: How professionals think in action. New York: Basic Books. 
Sikes, P., Measor, L., \& Woods, P. (1985). Teacher careers: Crises and continuities. London: The Falmer Press.

Skehan, P. (2000). A cognitive approach to language learning. Oxford: Oxford University Press.

Sockett, H. (1993). The moral base for teacher professionalism. New York: Teachers College, Columbia University.

Švaříček, R., Šed'ová, K., et al. (2007). Kvalitativní výzkum v pedagogických vědách. Praha: Portál.

Tsui, A. B. M. (2003). Understanding expertise in teaching. Cambridge: Cambridge University Press.

Tsui, A. B. M. (2005). Expertise in teaching: Perspectives and issues. In K. Johnson (Ed.), Expertise in second language teaching and learning (pp. 167-189). New York: Palgrave Macmillan.

Woods, P. (1981). Strategies, commitment and identity: Making and breaking the teacher role. In L. Barton \& S. Walker (Eds.), Schools, teachers and teaching (pp. 283-302). New York: Routledge.

Zembylas, M. (2003). Emotions and teacher identity: A poststructural perspective. Teachers and Teaching: Theory and Practice, 9(3), 213-238.

\section{Authors}

doc. Mgr. Světlana Hanušová, Ph. D., Masaryk University, Faculty of Education, Department of English Language and Literature, Poř́čí 7, 60300 Brno, Czech Republic, e-mail: hanusova@ped.muni.cz

doc. PhDr. Michaela Píšová, M.A., Ph. D., Masaryk University, Faculty of Education, Institute for Research in School Education, Poříćí 7, 60300 Brno, Czech Republic, e-mail: pisova@ped.muni.cz

Mgr. Klára Kostková, Ph. D., Charles University, Faculty of Education, Department of English Language and Literature, Celetná 13, 116 36, Praha, Czech Republic, e-mail: klarinak@gmail.com

prof. PhDr. Věra Janíková, Ph. D., Masaryk University, Faculty of Education, Department of German Language and Literature, Poříćí 7, 60300 Brno, Czech Republic, e-mail: janikova@ped.muni.cz

Mgr. Petr Najvar, Ph. D., Masaryk University, Faculty of Education, Institute for Research in School Education, Poříčí 7, 60300 Brno, Czech Republic, e-mail: najvar@ped.muni.cz

\section{Subjektivní determinanty expertnosti učitelů cizího jazyka}

Abstrakt: Článek přináší parciální výsledky výzkumného projektu, který se zabýval charakterem expertnosti učitelů cizího jazyka. Zatímco první dvě fáze projektu se zaměřovaly na expertní výkon učitele, poznatkovou bázi a vhled ze synchronní perspektivy, třetí fáze výzkumu byla orientovaná diachronně a jejím cílem byla identifikace subjektivních i objektivních determinant rozvoje expertnosti učitele. $\mathrm{V}$ textu představujeme výsledky vztahující se k subjektivním determinantám profesního rozvoje. 
Data jsme získali prostřednictvím narativních rozhovorů s osmi učiteli anglického a německého jazyka na nižším sekundárním stupni škol v České republice. Procesem otevřeného kódování jsme indukovali následující kategorie: učitelovo sebepoznání, vnitřní motivaci, hodnotový systém, pracovní spokojenost, otevřenost ke změně a zvládání náročnosti profese. Výsledky přispívají k porozumění procesu rozvoje a udržování expertnosti a též k porozumění potřebám učitelů a rozvoji podpůrných procesů jejich profesního rozvoje.

Klíčová slova: profesní rozvoj, učitel cizího jazyka, narativní interview, expertnost učitele, subjektivní determinanty 